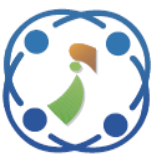

\title{
Performance Assessment of c-Si PV Module Under Real Operating Conditions in the City of El Jadida Morocco
}

\author{
Elhadi Baghaz ${ }^{1 *}$ \\ Charaf Hajjaj $^{2}$ \\ Rachid Bendaoud ${ }^{1}$ \\ Fatima Chanaa ${ }^{1}$ \\ Said Bounouar ${ }^{1}$ \\ Houssam Amiry ${ }^{1}$ \\ Bouchaib Zohal ${ }^{1}$ \\ Said Yadir ${ }^{3}$ \\ Mohammadi Benhmida ${ }^{1}$ \\ ${ }^{1}$ Laboratory of Electronics, Instrumentation and Energetic, Department of physics, Faculty of Sciences, \\ Chouaïb Doukkali University, El Jadida, Morocco \\ ${ }^{2}$ Laboratory of Applied Sciences for the Environment and Sustainable Development, \\ Higher School of Technology of Essaouira, Cadi Ayyad University, Essaouira, Morocco \\ ${ }^{3}$ Laboratory of Materials, Processes, Environment and Quality, National School of Applied Sciences, \\ Cadi Ayyad University, Safi, Morocco \\ * Corresponding author’s Email: baghaz.e@ucd.ac.ma
}

\begin{abstract}
In this paper, a new method of modeling PV modules in the Pspice simulator is proposed. This method consists in describing the behaviour of PV modules and the evolution of their I-V characteristics as a function of the temperature and the solar irradiance. The developed modelling technique is based on the internal physical parameters (photogenerated current (Iph), saturation current (Is), ideality factor (n) of the diode, series resistance (Rs) and shunt resistance (Rsh)) extracted using a high performance extraction method based on the experimental characteristics of the studied module. Experimental measurements of I-V characteristics were taken, under real operating conditions, using a high-precision I-V curve plotter. The values of these parameters are injected into the single diode model established under the Pspice simulator. This technique allows to construct with satisfactory simplicity the I-V curve of different PV module technologies under different environmental conditions. The comparison of simulation results and those obtained experimentally shows the accuracy of the used method. Furthermore, based on measured data, extracted saturation current, series resistance and ideality factor seem to be not influenced by the variation of the irradiance. Then, the comparison of the extracted parameters with those calculated by empirical laws proposed in literature, shows the reliability of these laws and this for the studied monocrystalline PV module. Moreover, it has been studied, experimentally and with empirical laws, the evolution of the efficiency and the power, of the studied PV module, as a function of the temperature. It appears that the rise of temperature from $25^{\circ} \mathrm{C}$ to $55^{\circ} \mathrm{C}$ deals with an electrical efficiency drop of about $2.2 \%$.
\end{abstract}

Keywords: C-Si PV module, Electrical efficiency, Performance assessment, Extraction method, PSpice simulator.

\section{Introduction}

Nowadays, the photovoltaic technologies of crystalline silicon materials like monocrystalline and poly-crystalline PV modules have dominated the PV market, owing to several factors, such as the price/performance ratio. While, the performance of the PV cell is strongly dependent to the behavior of its internal and external factors. To improve the performances of these technologies, the assessment of its physical and electrical parameters is indispensable. In this context, several studies have been done to characterize the PV module in PSpice simulator [1-4]. In these research works, the choice of internal parameters of a PV cell is done randomly, by varying their values, to bring the simulation curve closer to the experimental results, but with relatively low compatibility [1]. This poor compatibility results in a difference of: $7 \%$ at the short circuit point, $2.5 \mathrm{~W}$ $(5.55 \%)$ at the maximum power point (PPM) and $1 \mathrm{~V}$ $(4.87 \%)$ at the open circuit point [1]. Yet, these 
internal parameters can be extracted using extraction methods in which it is possible to obtain the exact value of PV cell internal parameters [5-9]. There are three types of method: graphic, analytical and numerical. The major drawback of graphical methods leads to larger errors than the errors characterizing experimental measurements $[10,11]$. Based on these methods, several research works have been done in order to evaluate the behavior of internal physical parameters as a function of irradiance and temperature [12-17].

Singh and Ravindra studied the temperature effect on the diode saturation current for silicon solar cells in a temperature range from $0{ }^{\circ} \mathrm{C}$ and $250^{\circ} \mathrm{C}$. They found an exponential variation for this parameter with increasing solar cell temperature [14].

Khan et al. [15] studied the behavior of the parameters of a monocrystalline silicon solar cell with a single diode in the range of $150-1800 \mathrm{~W} / \mathrm{m}^{2}$ for a constant temperature of $25^{\circ} \mathrm{C}$. They found that the ideality factor of the diode, the saturation current and serial resistance increases as a function of irradiance, while the shunt resistance decreases.

For an irradiance range of 160 to $1000 \mathrm{~W} / \mathrm{m}^{2}$, Chegaar et al. [16] studied the evolution of the parameters of a single-diode PV cell, in polysilicon at a temperature of $25^{\circ} \mathrm{C}$. They found an exponential increase in the saturation current of the diode, a linear increase in the factor ideally, linear decrease in shunt resistance and a series resistance invariant as a function of irradiance.

Arora et al. evaluated in its work the effect of temperature and irradiance on series resistance using illuminated and dark I-V curves. For a wide range of temperatures $\left(-173{ }^{\circ} \mathrm{C}\right.$ to $\left.227{ }^{\circ} \mathrm{C}\right)$, they found an increase of series resistance for both polycrystalline and single-crystal silicon solar cells [17].

In this paper, a new method of modelling PV modules in the Pspice simulator is presented. The physical parameters are extracted using a high precision extraction method described in another work [8]. This method is based on I-V experimental characteristics measured using a characterization device, developed and performed in our laboratory [13]. The extracted parameters values are introduced into the equations describing the behaviour of the electronic components that constitute the single diode model of the PV module. A comparison between the characteristics (I-V and P-V) obtained by simulation and those obtained experimentally is established in order to test the reliability of the developed method. After having modeled and characterized the PV module under Pspice environment, the evolution of the extracted parameters as a function of the solar irradiance at a constant temperature was done.
Moreover, it has been studied, experimentally and with empirical laws, the evolution of the efficiency and the power, of the studied PV module, as a function of the temperature.

Furthermore, this paper presents a preliminary study to move to the electro-thermal study of PV module, which allows to correctly estimate the electrical and thermal energy efficiency of a PVT system.

\section{PV module modeling based on extraction method}

\subsection{Description of the PV module modeling method in the pspice simulator}

This new modeling method of PV modules consists in implementing the electrical circuit of the PV cell, shown in Fig. 1, in the Pspice simulator. This circuit consists of photogenerated current $\left(I_{p h}\right)$, a diode with a saturation current $\left(I_{0}\right)$ and an ideality factor $(n)$, a shunt resistance $\left(R_{s h}\right)$ and a series resistance $\left(R_{s}\right)$. The PV cell simulation, in a Pspice simulator, requires knowledge of the last five parameters: $I_{p h}, R_{s}, R_{s h}, I_{0}, n$. A performing extraction method [10] is used in order to extract these parameters. This extraction method is based on the experimental characteristics of the PV module, measured using a curve plotter developed and performed in our laboratory [13]. After extracting and introducing the PV cell parameters to the designed model, 36 cells in series were connected to model the entire PV module (Fig. 2).

The characteristic equation corresponding to the equivalent circuit of the cell model is written as follows:

$I=I_{p h}-I_{0}\left[\exp \left(\frac{V+\left(I \times R_{S}\right)}{n \times V_{T}}\right)-1\right]-\frac{V+\left(I \times R_{S}\right)}{R_{S h}}$

where,

$$
\begin{array}{ll}
V_{T} & : \text { Thermodynamic potential }\left(V_{T}=k_{B} T / e\right), \\
k_{B} & : \text { Boltzmann constant }\left(1.38110^{-23} \mathrm{~J} / \mathrm{K}\right), \\
T & : \text { Effective cell temperature, } \\
e & : \text { Charge of the electron }\left(\mathrm{e}=1.610^{-19} \mathrm{C}\right) .
\end{array}
$$

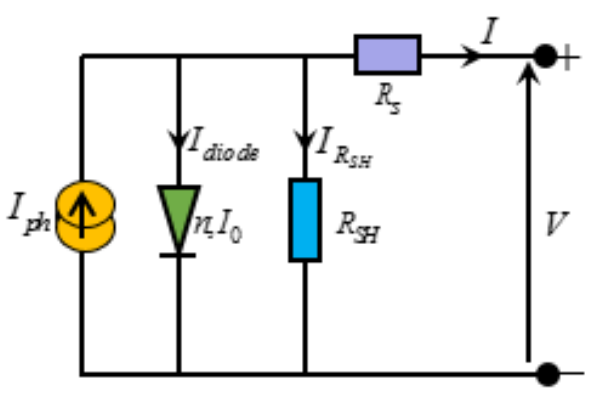

Figure. 1 Electrical scheme of PV cell 


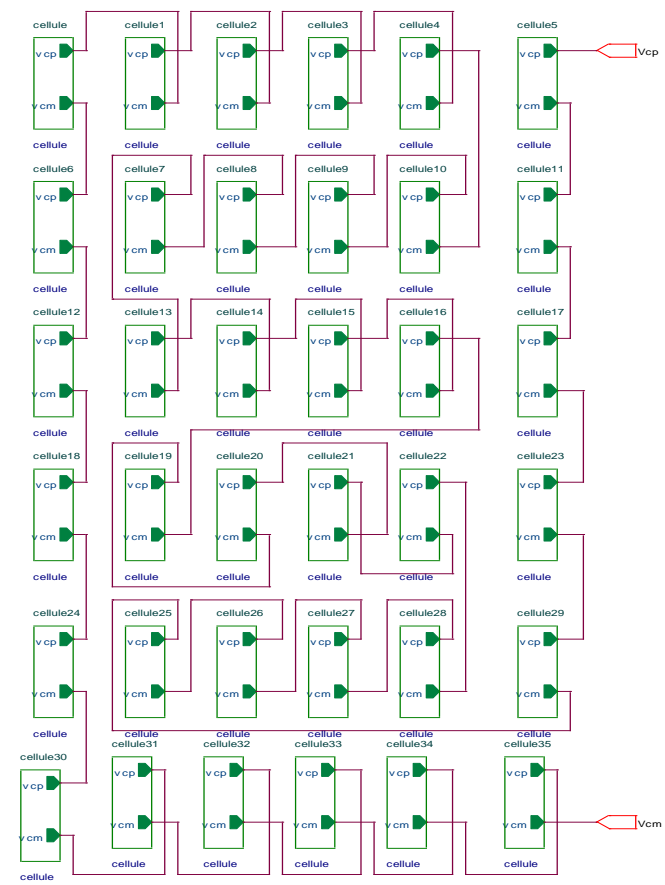

Figure. 2 PV module consisting of 36 PV cells in series in the Pspice simulator

\subsection{Description of TDC-M20-36 PV module}

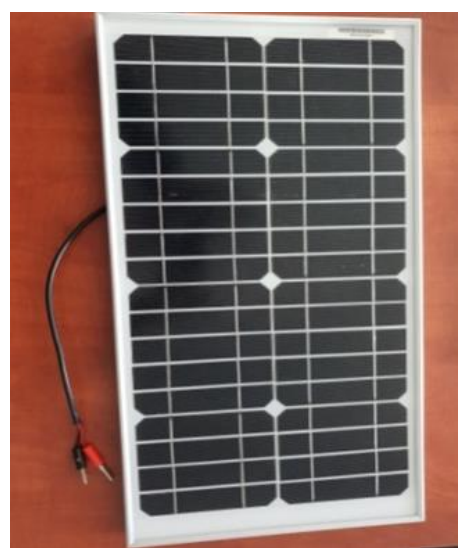

Figure. 3 Picture of the investigated PV module (TDCM20-36)

Table 1. Data sheet of the PV module supplied by the manufacturer

\begin{tabular}{|l|c|}
\hline PV characteristics & STC \\
\hline Maximum current intensity $\left(I_{\max }\right)[\mathrm{A}]$ & 1.12 \\
\hline $\begin{array}{l}\text { Voltage at the maximum power point }\left(V_{\max }\right) \\
{[\mathrm{V}]}\end{array}$ & 18 \\
\hline Maximum power point $\left(P_{\max }\right)[\mathrm{W}]$ & 20 \\
\hline Short circuit current $\left(I_{c c}\right)[\mathrm{A}]$ & 1.2 \\
\hline Open circuit voltage $\left(V_{o c}\right)[\mathrm{V}]$ & 21.24 \\
\hline Active surface of PV module $\left[\mathrm{m}^{2}\right]$ & 0.1125 \\
\hline Cells number connected in series $N_{S}$ & 36 \\
\hline Efficiency $(\%)$ & 17.77 \\
\hline
\end{tabular}

\subsection{Description of the new method of a PV cell parameters extraction}

The five physical parameters are at first extracted using a precise method..

The extraction method is based on a combination of a genetic algorithm and the simulated annealing algorithm [8]. The genetic algorithm is based on a subdivision of the fields of research of physical parameters into sub-fields.

This method consists on minimization of the error function $F(X)$ corresponding to the mean square error (RMSE) defined by [8-9]:

$$
F(X)=\operatorname{RMSE}(X)=\sqrt{\frac{\sum_{i=1}^{N}\left(f\left(V_{\text {exp }, i}, \mathrm{I}_{\text {exp }, i}, X\right)\right)^{2}}{N}}
$$

Where $\mathrm{N}$ is the number of experimental points $\left(V_{\text {exp }, i}, \mathrm{I}_{\text {exp }, i}\right)$ of the characteristic I-V and $f\left(V_{\text {exp }, i}\right.$, $\left.\mathrm{I}_{\text {exp }, i}, \mathrm{X}\right)$ is a parameter related to the difference between experimental and simulated current intensity defined by [8-9]:

$$
\begin{array}{r}
f\left(V_{\text {exp }, i}, \mathrm{I}_{\text {exp }, i}, \mathrm{X}\right)=\mathrm{I}_{\text {exp }, i}-\left\{I_{\mathrm{ph}}\right. \\
\left.\mathrm{I}_{0}\left(\exp \left(\frac{V_{\text {exp }, i}+\mathrm{R}_{S} I_{\text {exp }, i}}{\mathrm{nV}_{\mathrm{th}}}\right)-1\right)-\frac{V_{\text {exp }, i}+\mathrm{R}_{S} I_{\text {exp }, i}}{R_{\mathrm{SH}}}\right\}
\end{array}
$$

Where $X=\left(I_{\mathrm{ph}}, I_{0}, \mathrm{n}, R_{S}, R_{\mathrm{SH}}\right)$ is the solution vector of the physical parameters.

At first, a random generation of a set of physical parameters values (population) is performed in each sub-domain. The generated population is evaluated by calculating the error function corresponding to each subset of the generated values. Then, the best solution corresponding to the minimum of the error function is retained for each subdomain. By crossing the solutions found in all subdomains and evaluating the new crossover population using the error function, the best solution is found using the genetic algorithm. The latter solution is considered to be an initial solution for the simulated annealing algorithm. From this solution, the simulated annealing algorithm allows to converge towards the optimal solution of the physical parameters sought [10].

\section{Experiment and physical parameters}

\subsection{Automated measuring bench}

The experimental measurement set up used (Fig. 4) is fully automated. It consists mainly of an I-V curve tracer, a solarimeter (SL 200) to measure the solar irradiance in tilted plan and an infrared (IR) 


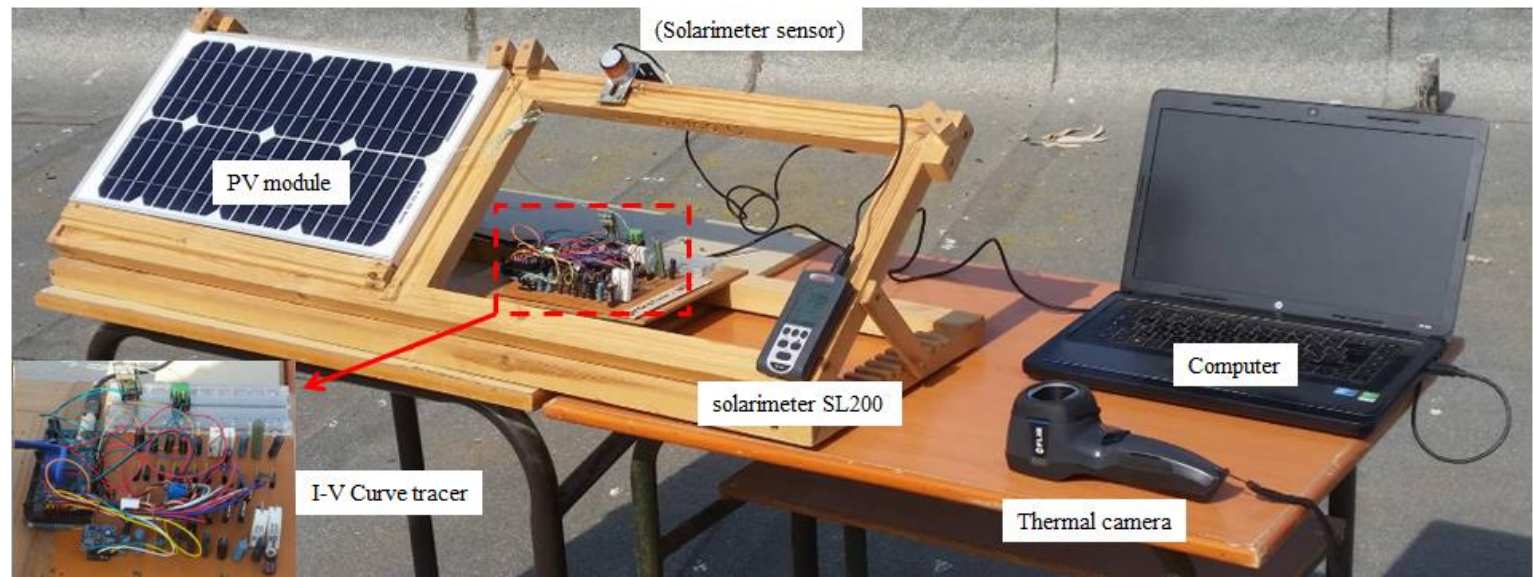

Figure. 4 Experimental measurement bench

Table 2. Extracted parameters from the PV cell for different irradiances

\begin{tabular}{|c|c|c|c|c|c|}
\hline Solar irradiance $\left(\mathrm{W} / \mathrm{m}^{2}\right)$ & 992 & 811 & 700 & 448 & 300 \\
\hline Extracted parameters & 3.5 & 2.67 & 2.7317 & 2.9664 & 3.1155 \\
\hline Diode saturation current $I_{0}\left(10^{-6} \mathrm{~A}\right)$ & 1.0783 & 0.9349 & 0.7831 & 0.4541 & 0.1634 \\
\hline Photogenerated current $I_{p h}(\mathrm{~A})$ & 28.7 & 32.514 & 35.6557 & 33.8133 & 56.7853 \\
\hline Shunt resistance $R_{s h}(\Omega)$ & 25.29 & 27.79 & 31.16 & 35.74 & 80.73 \\
\hline Series resistance $R_{s}(\mathrm{~m} \Omega)$ & 1.7526 & 1.7516 & 1.6820 & 1.7277 & 1.7282 \\
\hline Ideality factor $\mathrm{n}$ & & & & \\
\hline
\end{tabular}

camera of the FLIR i3 type to measure the temperature on the PV module surface. All of these elements are connected to data storage and processing unit.

The I-V curve tracer consists of an Arduino Mega 2560 control board, calibrated load resistors, MOSFET IRF540N and current, voltage and temperature sensors. It is an electronic circuit used to vary the load resistance automatically and to measure the voltage, current and operating temperature of PV module using appropriate sensors. This electronic circuit allows to measure a hundred points from the I-V characteristic of a PV module in a period of a few second. The taken measurements are transferred to the data acquisition station via the Arduino Mega 2560 board. The data acquisition process involves also measuring the incident solar irradiance on the plane of the PV module and thermal images to visualize the temperature evolution of the PV module front face.

\subsection{Cell parameters extraction}

As mentioned in paragraph 2.3, this extraction method [10] is based on the experimental I-V and P$\mathrm{V}$ characteristics of the PV module, which is the subject of this study. In this context, the PV module was characterized during a day with a solar irradiance varing from $300 \mathrm{~W} / \mathrm{m}^{2}$ to $1000 \mathrm{~W} / \mathrm{m}^{2}$ and for PV module temperature of $40^{\circ} \mathrm{C}$. Fig. 5 shows the I-V and V-P characteristics obtained in around $100 \mathrm{~ms}$.
Based on these characterization results, the PV cell parameters corresponding to each solar irradiance are extracted. The results obtained are shown in Table 2 below.

After having extracted the PV cell parameters for
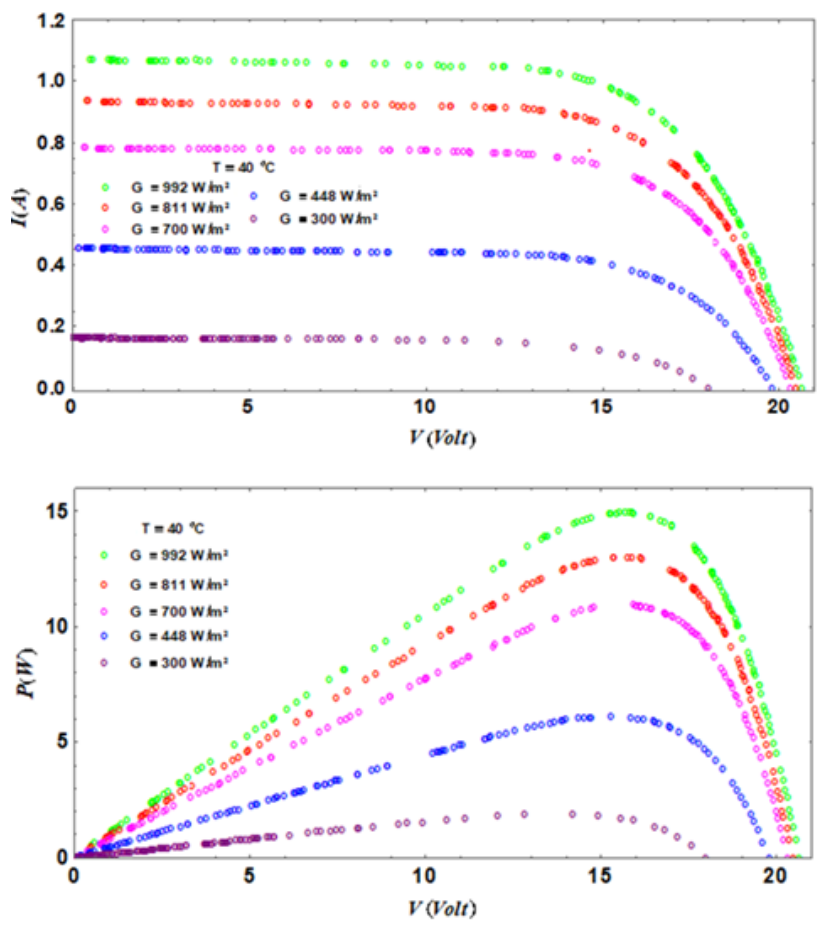

Figure. 5 Experimental current-voltage and powervoltage characteristics of the TDC-M20-36 PV module for different irradiance 


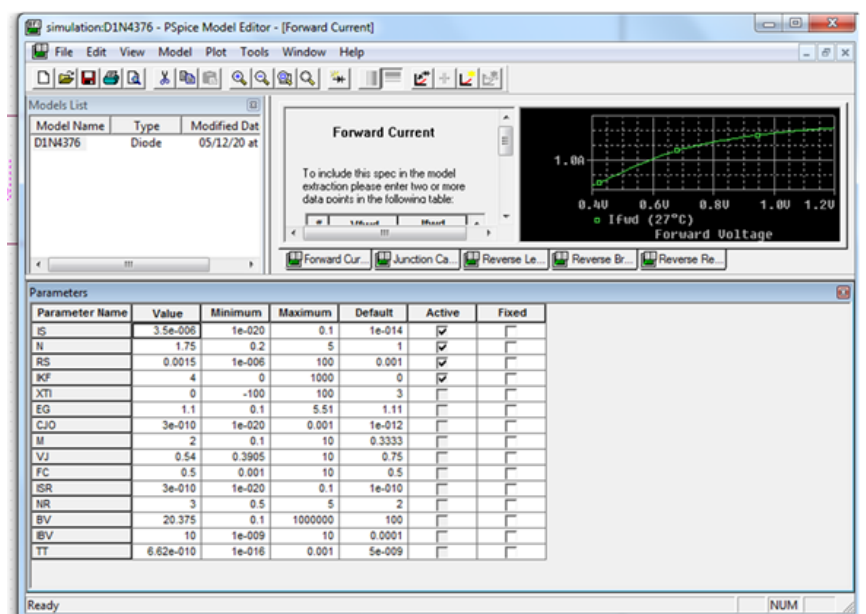

Figure. $6 \mathrm{PV}$ cell parameters, injected in orcad-pspice, for a solar irradiance of $992 \mathrm{~W} / \mathrm{m}^{2}$.
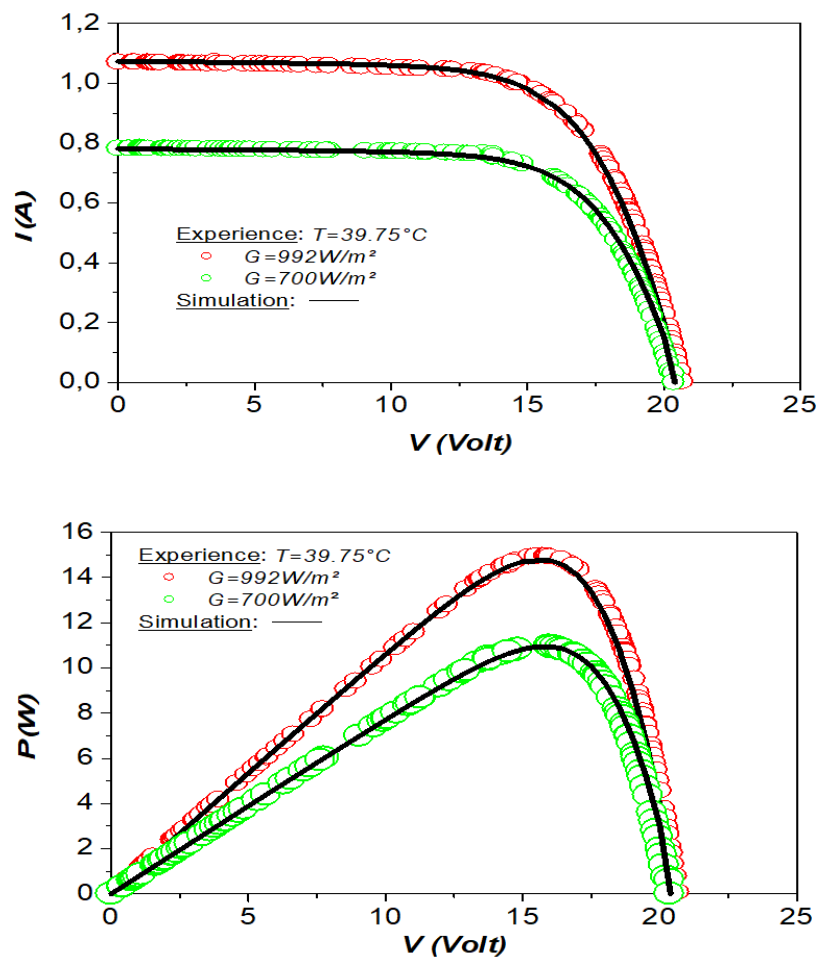

Figure. 7 Characteristics current-voltage and power tension for irradiances of 992 and $700 \mathrm{~W} / \mathrm{m}^{2}$ :

Experimental $(\mathrm{o}, \mathrm{o})$, and simulated in PSpice (-) considering the readjustment of the PV cell parameters, for a fixed temperature $\mathrm{T}=40^{\circ} \mathrm{C}$

the solar irradiance values cited above, we have inserted them in the Orcad-PSpice table presented in
Fig. 6. This table presents the PV cell parameters schematized in Fig. 2. The accuracy of these parameters is essential in order to have characteristics comparable with those obtained experimentally.

In order to deduce the performance of the used method for PV cell parameters extraction, the simulation results obtained are compared to the experimental ones (Fig. 7).

It is deduced that:

- The differences between experiment and simulation results for solar irradiances of $992 \mathrm{~W} / \mathrm{m}^{2}$ and $700 \mathrm{~W}$ $/ \mathrm{m}^{2}$ are of $0.46 \%$ and $2.24 \%$, for the maximum power point (PPM), and $1.61 \%$ and $0.2 \%$ for the open circuit point, respectively.

- This agreement between the above results clearly shows the accuracy of the used extraction method.

- For $992 \mathrm{~W} / \mathrm{m}^{2}$ and $700 \mathrm{~W} / \mathrm{m}^{2}$, the experimental efficiency of the TDC-M20-36 module is $13.44 \%$ and $14.12 \%$, respectively. An efficiency reduction

- of $22.45 \%$ compared to that given by the manufacturer.

- The comparison of the results obtained with those of Ouriachi and all [1] (Table 3) clearly shows the precision and reliability of the developed method.

\subsection{Influence of solar irradiance on physical parameters}

Fig. 8 shows the influence of solar irradiance on the PV module physical parameters at the temperature module of $40^{\circ} \mathrm{C}$.

It is deduced that:

- A linear dependence of the photogenerated current $I_{p h}$ to the solar irradiance (Fig. 8 (a)).

- A slight decrease in saturation current $\left(I_{0}\right)$ as a function of solar irradiance (Fig. 8 (b)).

- The series resistance $R_{s}$ varies slightly beyond 400 $\mathrm{W} / \mathrm{m}^{2}$ (Fig. 8 (c)). In addition, it experiences a sudden variation for a solar irradiance lower than 400W / $\mathrm{m}^{2}$.

Table 3. Precision comparison of the method developed with that of the method proposed by ouariachi and all [1]

\begin{tabular}{|c|c|c|c|}
\cline { 2 - 4 } \multicolumn{1}{c|}{} & \multicolumn{3}{c|}{ Difference between simulation and experimental results for $G=700 \mathrm{~W} / \mathrm{m}^{2}$} \\
\cline { 2 - 4 } & at the short-circuit point & $\begin{array}{c}\text { at maximum power point } \\
(P P M)\end{array}$ & at the open circuit point \\
\hline Developed method & $1.25 \%$ & $2.24 \%$ & $0.2 \%$ \\
\hline $\begin{array}{l}\text { Proposed method by } \\
\text { Ouariachi and all [1] }\end{array}$ & $\approx 7 \%$ & $\approx 5.55 \%$ & $\approx 4.87 \%$ \\
\hline
\end{tabular}



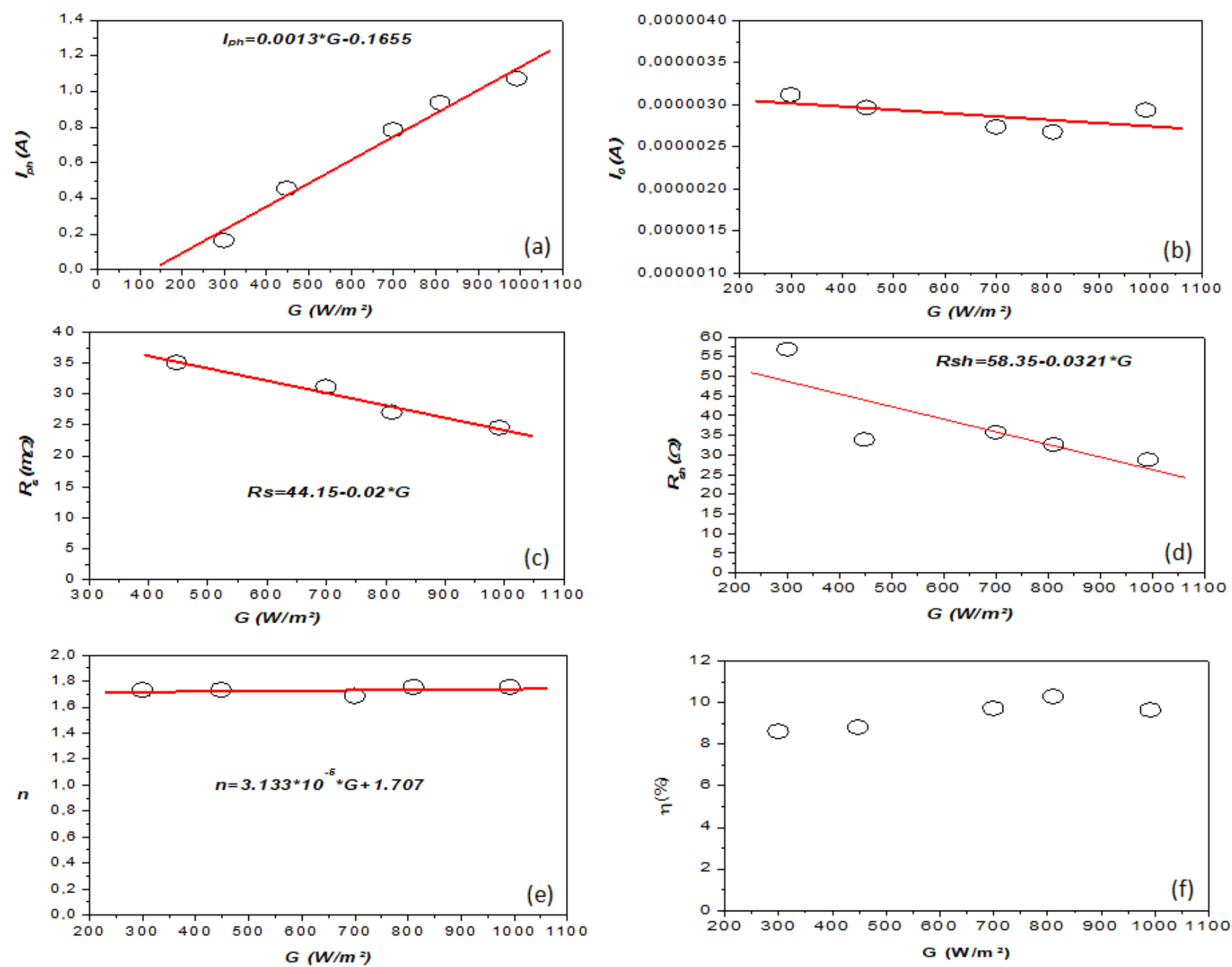

Figure. 8 Internal parameters of the TDC-M20-36 PV module at a fixed temperature of $40{ }^{\circ} \mathrm{C}$ : (a) short-circuit current $I_{c c}$, (b) diode saturation current $I_{0}$, (c) series resistance $R_{s}$, (d) shunt resistance $R_{s h}$, (e) ideality factor $n$, (f) electrical efficiency

- A decrease in the shunt resistance Rsh with the increase irradiance, going from $56.78 \Omega$ for 300 $\mathrm{W} / \mathrm{m}^{2}$ to $28.7 \Omega$ for $992 \mathrm{~W} / \mathrm{m}^{2}$ (Fig. 8 (d)).

- The ideality factor (n) is not influenced by solar irradiance variation, it remains almost constant (Fig. 8 (e)).

- The efficiency remains constant, oscillating around $13.5 \%$ whatever solar irradiance (Fig. 8 (f)).

\section{Comparison of the obtained results with the models proposed in the literature}

\subsection{Empirical laws proposed in literature:}

A variety of models allowing to calculate the PV module parameters $\left(I_{p h}, V_{o c} R_{s h}, R_{s}\right)$ are proposed in several studies [18-19]. Table 3 summarizes the PV module parameters calculated by different models proposed in literature, as well as their errors. The purpose of this study is to validate the obtained results and to classify the proposed models according to their accuracy

\section{Short-circuit current:}

The short-circuit current $I_{s c}$ is calculated by the empirical law presented by the equation Eq. (4) [18]. It depends on variation of both irradiance $G$ and temperature $T$ :

$$
I_{S C}(G, T)=\frac{G}{G_{S T C}}\left[I_{S C, S T C}+\mu_{I_{S C}}\left(T-T_{S T C}\right)\right]
$$

Or $\mu_{I s c}$ is the thermal coefficient of the shortcircuit current $\left(\mathrm{A} /{ }^{\circ} \mathrm{C}\right)$.

\section{Open-circuit voltage:}

The following empirical law predicts the open circuit voltage $V_{o c}$ of a PV module as a function of irradiance $G$ and temperature $T$ [25]: 


$$
\begin{gathered}
V_{O C}(G, T)=V_{O C, S T C}+C_{1} \ln \left(\frac{G}{G_{S T C}}\right) \\
+C_{2} \ln \left(\frac{G}{G_{S T C}}\right)^{2} \\
+C_{3} \ln \left(\frac{G}{G_{S T C}}\right)^{3}+m_{V_{O C}}\left(T-T_{S T C}\right)
\end{gathered}
$$

Or $C_{1}=5.468511 \times 10^{-2}, C_{2}=5.973869 \times 10^{-3}$ and $C_{3}=7.616178 \times 10^{-4}$ of silicon and $\mu_{V o c}$ is the thermal coefficient of the open circuit voltage $\left(\mathrm{V} /{ }^{\circ} \mathrm{C}\right)$.

\section{Photogenerated current:}

The photogenerated current is calculated by the empirical law [18-19] presented in equation Eq. (6). It depends also on the temperature $T$ and the irradiance $G$ :

$$
I_{p h}(G, T)=\left(\frac{G}{G_{S T C}}\right) I_{p h}(T)
$$

\section{Shunt and series resistances:}

The empirical laws of shunt resistance $R_{s h}$ and series resistance $R_{s}$, proposed in references [18-19], depend only on the irradiance $G$ :

$$
\begin{gathered}
R_{S h}(G)=\left(\frac{G_{S T C}}{G}\right) R_{S h}{ }_{S T C} \\
R_{S}(G)=\left(\frac{G_{S T C}}{G}\right) R_{S, S T C}
\end{gathered}
$$

\subsection{Comparative study between the calculated parameters and those extracted from the PV module}

In order to predict the accuracy of the empirical laws cited above, we have compared the obtained PV module parameters $\left(V_{o c}, I_{p h}, R_{s h}, R_{s}\right)$ with those calculated by the empirical laws cited above, for an irradiance of $992 \mathrm{~W} / \mathrm{m}^{2}$ and a temperature of $40{ }^{\circ} \mathrm{C}$. The various results are shown in Table 4 . It appears

Table 4. Comparison of the extracted parameters with

\begin{tabular}{|c|l|l|l|l|}
\multicolumn{1}{c|}{ those calculated at $G=992 \mathrm{~W} / \mathrm{m}^{2}$ and $T=40^{\circ} \mathrm{C}$} \\
\cline { 2 - 5 } & $\begin{array}{l}V_{o c}(\mathrm{~V}) \\
\left(\begin{array}{l}\text { Eq. } \\
(5))\end{array}\right.\end{array}$ & $\begin{array}{l}I_{p h}(\mathrm{~A}) \\
(\mathrm{Eq})\end{array}$ & $\begin{array}{l}\left.R_{s h}(\Omega)\right) \\
(\mathrm{Eq} . \\
(8))\end{array}$ & $\begin{array}{l}R_{s}(\mathrm{~m} \Omega) \\
(\mathrm{Eq} . \\
(9))\end{array}$ \\
\hline Empirical laws & 21.12 & 1.06967 & 27.72 & 25.2 \\
\hline $\begin{array}{c}\text { developed } \\
\text { extraction } \\
\text { method }\end{array}$ & $\mathbf{2 0 . 8}$ & $\mathbf{1 . 0 7 8 3}$ & $\mathbf{2 8 . 7}$ & $\mathbf{2 5 . 9 2}$ \\
\hline $\begin{array}{c}\text { Absolute error } \\
(\%)\end{array}$ & $1.8 \%$ & $0.8 \%$ & $3.41 \%$ & $2.77 \%$ \\
\hline
\end{tabular}

that the empirical laws of the calculated parameters are closer to those obtained by the developed extraction method with an absolute error which does not exceed $3.5 \%$.

\section{Evolution of physical parameters as a function of temperature}

Fig. 9 below shows the influence of temperature on optimal power and electrical efficiency. A good reliability between experimental results and those calculated by empirical laws is considered. These empirical laws for optimal power and efficiency are given successively by Eq. (9) and (10) [13, 18-19].

$$
P_{\max }(T, G)=\mathrm{P}_{\max , \text { ref }} \frac{G}{G_{0}}[1-\gamma(T-25)]
$$

Where $\gamma$ is the temperature correction coefficient of the maximum power $\left(\gamma=-0.005 /{ }^{\circ} \mathrm{C}\right.$ to $-0.003 /{ }^{\circ}$ C) and $P_{\max , r e f}$ is the maximum power at SRC.

$$
\eta=\eta_{\text {ref }}\left[1-\beta_{\text {ref }}\left(\mathrm{T}-\mathrm{T}_{\mathrm{ref}}\right)+\gamma_{1} \ln \frac{G}{G_{0}}\right]
$$

Where $T_{r e f}, \eta_{\text {ref }}, \beta_{\text {ref }}$ and $\gamma_{1}$ are the reference temperature, the efficiency at the reference
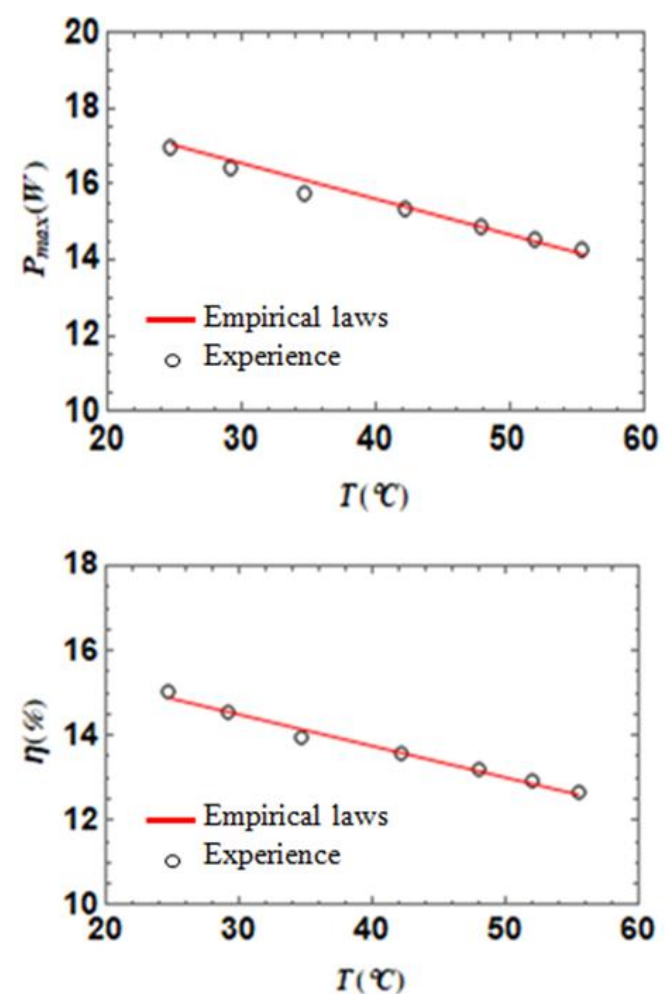

Figure. 9 Evolution of the maximum power $P_{\max }$ and efficiency $\eta$ as a function of the temperature for $\mathrm{G} \approx 1003$ $/ \mathrm{m}^{2}$ 
Table 5. Temperature correction coefficients associated to the monocrystalline PV module studied

\begin{tabular}{|l|l|l|}
\hline Parameters & $P_{\max }$ & $\eta$ \\
\hline $\begin{array}{l}\text { Calculated temperature } \\
\text { correction coefficients } \\
\left(\% /{ }^{\circ} \mathrm{C}\right)\end{array}$ & $\gamma=0.55$ & $\beta_{\text {ref }}=0.49$ \\
\hline $\begin{array}{l}\text { Temperature correction } \\
\text { coefficients reported in } \\
\text { the literature }\left(\% /{ }^{\circ} \mathrm{C}\right)\end{array}$ & 0.37 à 0.52 & 0.38 à 0.52 \\
\hline
\end{tabular}

temperature measured in SRC, the temperature correction coefficient for the efficiency and the irradiance coefficient, respectively.

The results show that:

- By varying the temperature from $25^{\circ} \mathrm{C}$ to $55^{\circ}$ $\mathrm{C}$, the optimal power of the $\mathrm{PV}$ module decreases from $17 \mathrm{~W}$ to $14 \mathrm{~W}$, that is a decrease of $17.64 \%$.

- $\quad$ For the same temperature variation, the electrical efficiency of the PV module decreases from $15 \%$ to $12.8 \%$, that is a decrease of $2.2 \%$.

The temperature correction coefficients $\gamma$ and $\beta_{\text {ref }}$ associated respectively with $P_{\max }$ and $\eta$ by application of empirical laws have been determined as shown in Eqs. 9 and 10 and Table 5. These values are also in good agreement with the results reported in the literature [27, 28].

\section{Conclusion}

This study contributes to enrich knowledge of performance assessment of the c-Si module through the investigation of the effect of solar irradiance on the physical parameters. In-situ developed method has been used to extract the physical parameters (series $\left(R_{s}\right)$ and shunt $\left(R_{s h}\right)$ resistances, saturation current and the ideality factor $(n))$ of c-Si PV technologies using experimental data measured under real operating conditions. These parameters are injected in Orcad-PSpice in order to modeling the electrical parameters of PV cell as a function of Irradiance and temperature.

The results of this study show:

- An agreement between the experimental and simulation results, which improve the accuracy of the used extraction method.

- Performance degradation of PV module with an efficiency drop of $2.2 \%$.

- $\quad$ Slight variation of saturation current, the series resistance and the ideality factor as a function of solar irradiance.

- Slight decreases of shunt resistance as a function of solar irradiance, varying from $56 \Omega$ for $300 \mathrm{~W}$ $/ \mathrm{m}^{2}$ to $28 \Omega$ for $992 \mathrm{~W} / \mathrm{m}^{2}$.
The confrontation of the extracted parameters $\left(I_{p h}, I_{s a}, V_{o c}, R_{s h}\right.$ et $R_{s}$ ) with those calculated by empirical laws proposed in literature, shows that they are in good agreement with an error that does not exceed $4 \%$.

Electrical efficiency drop of about $2.2 \%$ for the rise of $\mathrm{PV}$ module temperature from $25^{\circ} \mathrm{C}$ to $55^{\circ} \mathrm{C}$.

- The results of this work will be a preliminary investigation of the electro-thermal behavior of the c-Si PV technology.

\section{Conflicts of Interest}

The authors declare no conflict of interest.

\section{Author Contributions}

Each author's contribution is as follows: Conceptualization, Elhadi Baghaz and Mohammadi Benhmida; methodology, Elhadi Baghaz, Rachid Bendaoud, Fatima Chanaa and Mohammadi Benhmida; software, Elhadi Baghaz and Rachid Bendaoud; validation, Elhadi Baghaz, Rachid Bendaoud, Fatima Chanaa and Said Bounouar; formal analysis, Elhadi Baghaz, Rachid Bendaoud, Fatima Chanaa and Charaf Hajjaj; investigation, Elhadi Baghaz, Houssam Amiry, Bouchaib Zohal, Mohammadi Benhmida, and Said Yadir; resources, Mohammadi Benhmida; data curation, Elhadi Baghaz and Mohammadi Benhmida; writingoriginal draft preparation, Elhadi Baghaz, Rachid Bendaoud, Fatima Chanaa, Charaf Hajjaj and Said Bounouar; writing - review and editing, Elhadi Baghaz, Fatima Chanaa, Rachid Bendaoud, Charaf Hajjaj and Mohammadi Benhmida; visualization, Elhadi Baghaz, Mohammadi Benhmida, Houssam Amiry, Bouchaib Zohal and Said Yadir; supervision, Mohammadi Benhmida and Elhadi Baghaz; project administration, Mohammadi Benhmida and Elhadi Baghaz.

\section{References}

[1] M. El Ouariachi, T. Mrabti, B. Tidhaf, Ka. Kassmi, and K. Kassmi, "Regulation of the electric power provided by the panels of the photovoltaic systems", International Journal of Physical Sciences, Vol. 4, No. 5, pp. 294-309, 2009.

[2] T. Mrabti, M. El Ouariachi, B. Tidhaf, and K. Kassmi, "Caractérisation et modélisation fine du fonctionnement électrique des panneaux photovoltaïques", Revue des Energies Renouvelables, Vol. 12, No. 3, pp. 489-500, 2009. 
[3] T. Mrabti, M. El Ouariachi, B. Tidhaf, Ka. Kassmi, and E. Chadli, and K. Kassmi, "Modélisation des propriétés électriques et caractérisation des panneaux photovoltaïques", Revue des Energies Renouvelables, Vol. 12 No. 1, pp. 105-116, 2009.

[4] T. Mrabti, M. El Ouariachi, B. Tidhaf, El Chadli, and K. Kassmi, "Conception, simulation et réalisation d'un système photovoltaïque destiné au stockage d'énergie dans les batteries stationnaires (2V)", Revue des Energies Renouvelables, Vol. 13, No. 1, pp. 85-100, 2010.

[5] J. Bai, S. Liu, Y. Hao, Z. Zhang, M. Jiang, and Y. Zhang, "Development of a new compound method to extract the five parameters of PV modules", Energy Convers Manag, Vol. 79, pp. 294-303, 2014.

[6] Y. Chaibi, M. Salhi, A. El-jouni, and A. Essadki, "A new method to extract the equivalent circuit parameters of a photovoltaic panel", Sol. Energy, Vol. 163, pp. 376-386, 2018.

[7] A. R Jordehi, "Parameter estimation of solar photovoltaic (PV) cells: a review", Renew. Sustain Energy Rev, Vol. 61, pp. 354-371, 2016.

[8] R. Bendaoud, H. Amiry, M. Benhmida, B. Zohal, S. Yadir, S. Bounouar, C. Hajjaj, E. Baghaz, and M. ElAyd, "New method for extracting physical parameters of PV generators combining an implemented genetic algorithm and the simulated annealing algorithm", Solar Energy, Vol. 194, pp. 239-247240, 2019.

[9] X. Gao, Y. Cui, J. Hu, G. Xu, Z. Wang, and J. $\mathrm{Qu}$, "Parameter extraction of solar cell models using improved shuffled complex evolution algorithm", Energy Conversion and Management, Vol. 157, pp. 460-79, 2018.

[10] J. P. Ram, T. S. Babu, T. Dragicevic, and N. Rajasekar, "A new hybrid bee pollinator flower pollination algorithm for solar PV parameter estimation", Energy Conversion and Management, Vol. 135, pp. 463-76, 2017.

[11] K. Ishibashi, Y. Kimura, and M. Niwano, "An extensively valid and stable method for derivation of all parameters of a solar cell from a single current-voltage characteristic", J. Appl. Phys, Vol. 103, p. 094507, 2008.

[12] J.-P. Charles, A. Haddi, A. Maouad, H. Bakhtiar, A. Zerga, A, Hoffmann, and P. Mialhe, "La Jonction, du Solaire à la Microélectronique", Revue des Energies Renouvelables, Vol. 3, pp. 1-16, 2000.

[13] H. Amirya, M. Benhmidaa, R. Bendaouda, C. Hajjaja, S. Bounouara, S. Yadira, b, K. Raïsa, and M. Sidki, "Design and implementation of a photovoltaic I-V curvetracer: Solar modules characterization under real operating conditions", Energy Conversion and Management, Vol. 169, pp. 206-216, 2018.

[14] P. Singh and N. M. Ravindra, "Temperature dependence of solar cell performance - an analysis", Sol. Energy Mater. Sol. Cells, Vol. 101, pp. 36-45, 2012.

[15] F. Khan, S. N. Singh, and M. Husain, "Determination of diode parameters of a silicon solar cell from variation of slopes of the I - V curve at open circuit and short circuit conditions with the intensity of illumination Semicond", Sci. Technol, Vol. 25, 015002, 2010.

[16] M. Chegaar, A. Hamzaoui, A. Namoda, P. Petit, M. Aillerie, and A. Herguth, "Effect of illumination intensity on solar cells parameters", Energy Procedia, Vol. 36, pp. 722-729, 2013.

[17] J. D. Arora, A. V. Verma, and M. Bhatnagar, "Variation of series resistance with temperature and illumination level in diffused junction polyand single-crystalline silicon solar cells", $J$. Mater. Sci. Lett., Vol. 5, pp. 1210-1212, 1986.

[18] N. Anani and H. Ibrahim, "Adjusting the SingleDiode Model Parameters of a Photovoltaic Module with Irradiance and Temperature", Energies, Vol. 13, 3226, 2020.

[19] S. Yadir, R. Bendaoud, A. EL-Abidi, H. Amiry, M. Benhmida, S. Bounouar, B. Zohal, H. Bousseta, A. Zrhaiba, and A. Elhassnaoui, "Evolution of the physical parameters of photovoltaic generators as a function of temperature and irradiance: New method of prediction based on the manufacturer's datasheet", Energy Conversion and Management, Vol. 203, No. 141, pp. 1-12, 2020. 